2. To: (Receiving organization) BWHC 327 Projects

5. Proj./Prog./Dept./Div.:

327 Legacy Waste Project

8. Originator Remarks:

None

11. Receiver Rentarks:

None
3. From: (Originating Organization) BWHC 327 Projects

6. Design Authority/ Design Agent/Cog. Engr.: J. F. Henderson
4. Related EDT No.:

$N / A$

7. Purchase Order No.

$$
N / A
$$

9. Equip./Component No.: $\mathrm{N} / \mathrm{A}$

10. System/Bldg./Facility: 327 Building

12. Major Assm. Dwg. Mo.:

11A. Design Baseline Document? [] Yes [X] No N/A

13. Permit/Permit Application No.: N/A

14. Required Response Date: $N / A$

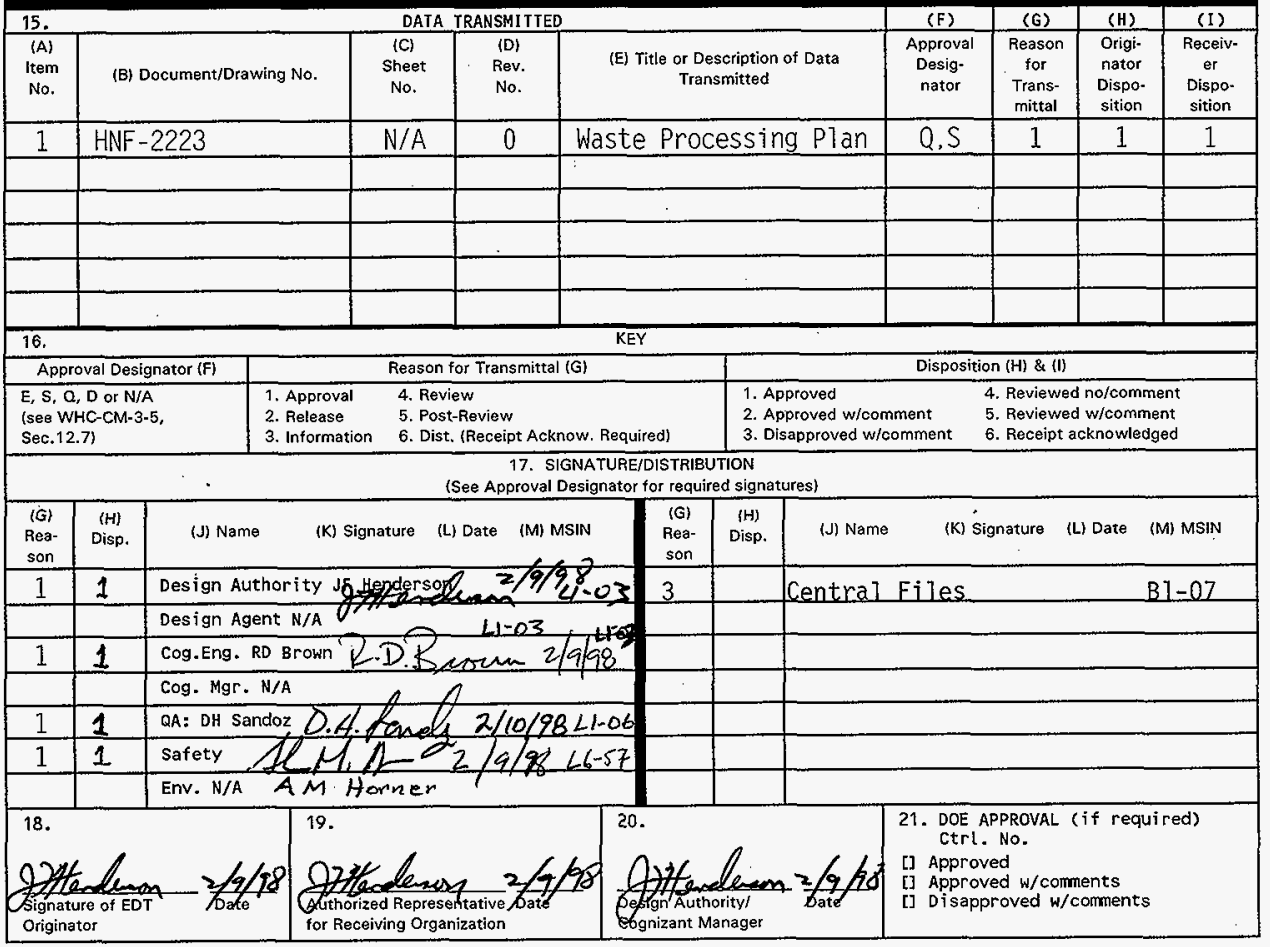

BD-7400- $772-2(05 / 96)$ GEF097 
HNF-2223, Rev. 0

\section{Legacy Waste Processing Plan}

\section{J. F. Henderson}

B\&W Hanford Company, Richland, WA 99352

U.S. Department of Energy Contract DE-AC06-96RL13200

$\begin{array}{lll}\text { EDT/ECN: } & 623053 & \text { UC: } 2000 \\ \text { Org Code: } & 19340 & \text { Charge Code: K7MLW (HAN98400) } \\ \text { B\&R Code: } & \text { EW7002010 } & \text { Tota7 Pages: } 7\end{array}$

Key Words: 327 Legacy Waste Project, Waste Processing PIan, 327 Facility, Postirradiation Testing Laboratory, PTL, Hot Cells, Performance Agreement (PA) Milestone, Central Waste Complex, CWC

Abstract: The B\&W Hanford Company's (BWHC) 327 Facility [Postirradiation Testing Laboratory (PTL)] houses 10 hot cells in which a variety of postirradiation examinations have been performed since its construction in the mid 1950s. Over the years, the waste that was generated in these cells has been collected in one gallon buckets. These buckets are essentially one gallon cylindrical cans made of thin wall stainless steel with welded bottoms and slip fit lids. They contain assorted compactable waste (i.e., Wipe-Alls, Q-tips, towels etc.) as well as non-compactable waste (i.e., small tools, pieces of metal tubing, etc.). There is a FY-98 BWHC Performance Agreement (PA) milestone in place to package 200 of these buckets in drums and ship them from the 327 facility to the Central Waste Complex (CWC) by September $30,1998$.

TRADEMARK DISCLAIMER. Reference herein to any specific commercial product, process, or service by trade name, trademark, manufacturer, or otherwise, does not necessarily constitute or imply its endorsement, recomendation, or favoring by the United States Government or any agency thereof or its contractors or subcontractors.

Printed in the united states of America. To obtain copies of this document, contact: HHC/BCS Document Control Services, P.0. Box 1970, Maflstop 166-08, Richland wA 99352, Phane (509) 372-2420; Fax (509) 376-4989.

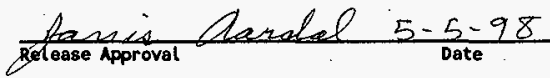

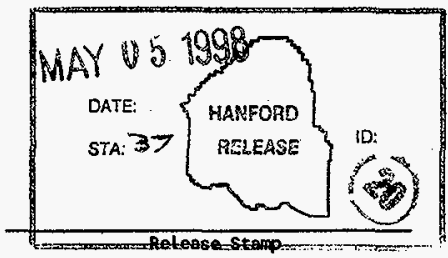




\title{
327 LEGACY WASTE PROCESSING PLAN
}

\author{
HNF-2223 \\ Revision 0
}

\author{
by \\ J. F. Henderson \\ Manager \\ 327 Projects \\ B\&W Hanford Company \\ R.D. Brown \\ Engineering \\ B\&W Hanford Company
}

February 09, 1998 


\section{LEGACY WASTE PROCESSING PLAN HNF-2223 Rev. 0}

The B\&W Hanford Company's (BWHC) 327 Facility [Postirradiation Testing Laboratory (PTL)] houses 10 hot cells in which a variety of postirradiation examinations have been performed since its construction in the mid 1950's. Over the years, the waste that was generated in these cells has been collected in one gallon buckets. These buckets are essentially one gallon cylindrical cans made of thin wall stainless steel with welded bottoms and slip fit lids. They contain assorted compactable waste (i.e. Wipe-Alls, Q-tips, towels, etc.) as well as noncompactable waste (i.e. small tools, pieces of metal tubing, etc.) There is a FY98 BWHC Performance Agreement (PA) milestone in place to package 200 of these buckets in drums and ship them from the 327 facility to the Central Waste Complex (CWC) by September 30, 1998.

The buckets will be removed by performing 10 campaigns of 20 buckets each. Buckets for each campaign will be selected at the discretion of the Person-in-Charge (PIC). The bucket selection process may be based on whether or not a particular cell needs to be cleaned out; the availability of waste containers (concrete-lined drum or lead-lined drum); or whether a certain level of bucket characteristic (rad level reading) is desired to finish filling a waste container.

Unreviewed Safety Question (USQ) reviews of the operating procedures controlling the project activities have concluded that these activities fall within the 327 Building authorization basis (HNF-SD-SPJ-SAR-002, 327 Building Safety Analysis Report). The operating procedures have also been reviewed and approved by BWHC Safety and Industrial Hygiene. All packaging of radioactive materials is performed within either hot cells or packages having approved ventilation controls in place to prevent unauthorized release to the environment, which is consistent with facility environmental permits.

The following steps describe the overall process. See Table 1 (Quality Control Matrix) for specific details and controls.

\section{INVENTORYAND TRANSFER BUCKETS TO C-CELL}

After the buckets have been identified, they shall be transferred to C-cell for radiation characterization. The transfer of buckets shall be conducted using procedures 3M-SOP-PTL118, Sample Material Transfers and Inventory Postings, 3M-SOP-PTL-143, Removal and Reinstallation of Solid Access Plugs and Slide Plugs, and 3M-SOP-PTL-167, Receiving, Loading/Unloading, and Shipping SERF Casks. As an option to the use of the SERF cask, the Waste Cask may be used per procedure 3M-SOP-PTL-168, Receiving, Loading/Unloading, and Shipping Waste Casks, for the transfer of buckets from cell to cell.

\section{CHARACTERIZE BUCKETS AND MARK ENDS}

Once the buckets are in C-cell, they will be characterized by radiation readings using an RO7A probe. Prior to taking readings on the buckets, the bucket number shall be written with an indelible marker on the top and bottom of the bucket to ensure the bucket can be 


\section{HNF-2223 Rev. 0}

tracked (once the bucket is compacted the number on the side of the bucket may no longer be discernible). Also prior to characterization, the probe's calibration shall be verified (calibration is annual). If the probe needs to be calibrated, it shall be sent to Pacific Northwest National Laboratory (PNNL) for calibration. The radiation readings will be taken by placing the buckets in front of the RO7A probe that is currently installed in C-cell. Buckets that have readings up to and including $7 \mathrm{R} / \mathrm{hr}$ will be packaged into the concretelined drum. Buckets with readings exceeding $7 \mathrm{R} / \mathrm{hr}$ will be packaged in a lead-lined drum. The $7 \mathrm{R} / \mathrm{hr}$ trigger level may change depending on the actual radiation measurements made of the first few drums. Shipping requirements state that the radiation level on the exterior of the drums shall be not greater than $100 \mathrm{mrem} / \mathrm{hr}$ on contact.

\section{TRANSFER BUCKETS TO A-CELL \& PACKAGE}

Following characterization, the buckets shall be transferred to A-cell for compacting and packaging into the sleeves. The transfer of buckets shall be conducted using procedures $3 \mathrm{M}$ SOP-PTL-143 and either 3M-SOP-PTL-167 or 3M-SOP-PTL-168. The compacting and packaging shall be performed per procedures 3M-SOP-PTL-129, In-Cell Compacting \& Packaging of TRU Waste for Disposal (A-Cell) and the welding of the lead-lined drum sleeve per 3M-SOP-PTL-159, A-Cell RHTRU Waste Package Welding Procedure. Upon completion of all steps in these procedures, the loaded drums will be staged for shipment.

\section{ASSAY DRUMS AND CONFIRM "READY TO SHIP"}

Once the drums are staged for shipment, they shall be assayed by PNNL's NDA group (Dosimetry Research \& Technology). The purpose of the NDA is to determine whether any TRU material is present in the packaged waste and, if so, how much of it exists per drum. The shipping criteria states that the maximum allowable amount of fissile material that may be present in a lead-lined drum is 100 grams. The shipping criteria for the concrete-lined drum is currently under revision to increase the maximum allowable amount of fissile material from 15 to 100 grams. Two lead-lined drums or six concrete-lined drums will constitute one shipment and it is at the discretion of the PIC as to how many drums need to be ready for shipment prior to contacting PNNL for NDA services. PNNL's NDA services shall be responsible for ensuring that the assay equipment is calibrated to current standards.

\section{SHIP DRUMS}

After the drums are assayed, the assay results will be included in the transfer documentation (portfolio) required by WMH for shipping. When the portfolio is accepted by WMH, the drums will be shipped at the discretion of the CWC.

The 327 Legacy Waste Processing Plan Quality Control Matrix, is attached. This matrix identifies the order in which activities take place, applicable procedures and instructions, the responsible (lead) individual(s), and those activities requiring $\mathrm{QC}$ verification. 
HNF-2223 Rev. O

Table 1

1K7F0A 327 LEGACY WASTE PROJECT

QUALITY CONTROL MATRIX

\begin{tabular}{|c|c|c|c|c|c|}
\hline Activity & Product & $\begin{array}{l}\text { Work } \\
\text { Control } \\
\text { Number } \\
\text { (JCS No.) }\end{array}$ & $\begin{array}{l}\text { Applicable } \\
\text { Procedures } \\
\text { and } \\
\text { Instructions }\end{array}$ & $\begin{array}{l}\text { Responsible } \\
\text { (Lead) } \\
\text { Individual }\end{array}$ & $\begin{array}{l}\text { QA/QC } \\
\text { Requirements }\end{array}$ \\
\hline 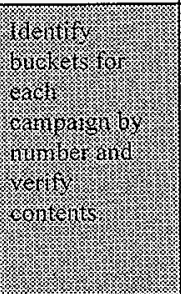 & 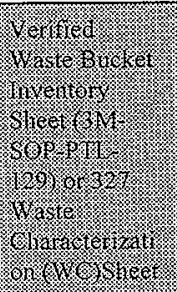 & x & 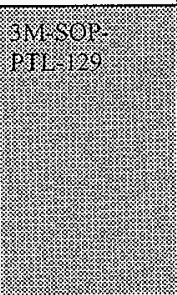 & 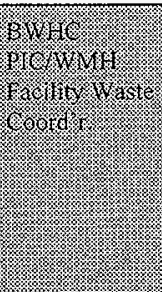 & 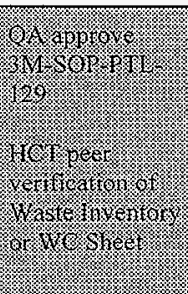 \\
\hline 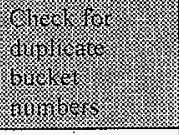 & 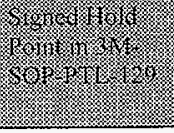 & & $\frac{1}{4}$ & (1) & 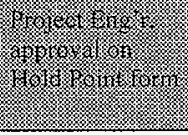 \\
\hline $\begin{array}{l}\text { Transfer } \\
\text { identified } \\
\text { buckets for } \\
\text { given } \\
\text { campaign to } \\
\text { C-cell }\end{array}$ & $\begin{array}{l}\text { Sample } \\
\text { Transfer } \\
\text { Record Sheet } \\
(3 \mathrm{M}-\mathrm{SOP}- \\
\text { PTL-118) }\end{array}$ & & $\begin{array}{l}3 \mathrm{M}-\mathrm{SOP}- \\
\text { PTL-118, 129, } \\
167,168\end{array}$ & BWHC PIC & $\begin{array}{l}\text { QA approve } \\
\text { 3M-SOP-PTL- } \\
118\end{array}$ \\
\hline $\begin{array}{l}\text { Verify RO-7A } \\
\text { probe } \\
\text { instrument cal. }\end{array}$ & $\begin{array}{l}\text { Up-to-date } \\
\text { calibration }\end{array}$ & N/A & $\begin{array}{l}\text { Applicable } \\
\text { step in 3M- } \\
\text { SOP-PTL-129 }\end{array}$ & BWHC PIC & None \\
\hline $\begin{array}{l}\text { Characterize } \\
\text { buckets } \\
\text { (RO7A) for } \\
\text { packaging \& } \\
\text { identify } \\
\text { pathway }\end{array}$ & $\begin{array}{l}\text { Waste Bucket } \\
\text { Inventory or } \\
\text { WC sheet }\end{array}$ & N/A & $\begin{array}{l}\text { 3M-SOP- } \\
\text { PTL-129 }\end{array}$ & $\begin{array}{l}\text { BWHC } \\
\text { PIC/BWHC } \\
327 \text { RadCon } \\
\text { Supv. }\end{array}$ & None \\
\hline (1) & 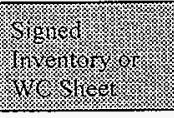 & 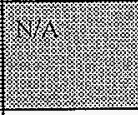 & 格 & 9 & 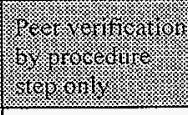 \\
\hline $\begin{array}{l}\text { Transfer } \\
\text { buckets to A- } \\
\text { cell for } \\
\text { packaging }\end{array}$ & $\begin{array}{l}\text { Sample } \\
\text { Transfer } \\
\text { Record Sheet } \\
\text { (3M-SOP- } \\
\text { PTL-118) } \\
\end{array}$ & N/A & $\begin{array}{l}\text { 3M-SOP- } \\
\text { PTL-118, } 129 \\
167,168\end{array}$ & BWHC PIC & None \\
\hline
\end{tabular}


HNF-2223 Rev. 0

Table 1 (continued)

\section{K7FOA 327 LEGACY WASTE PROJECT QUALITY CONTROL MATRIX}

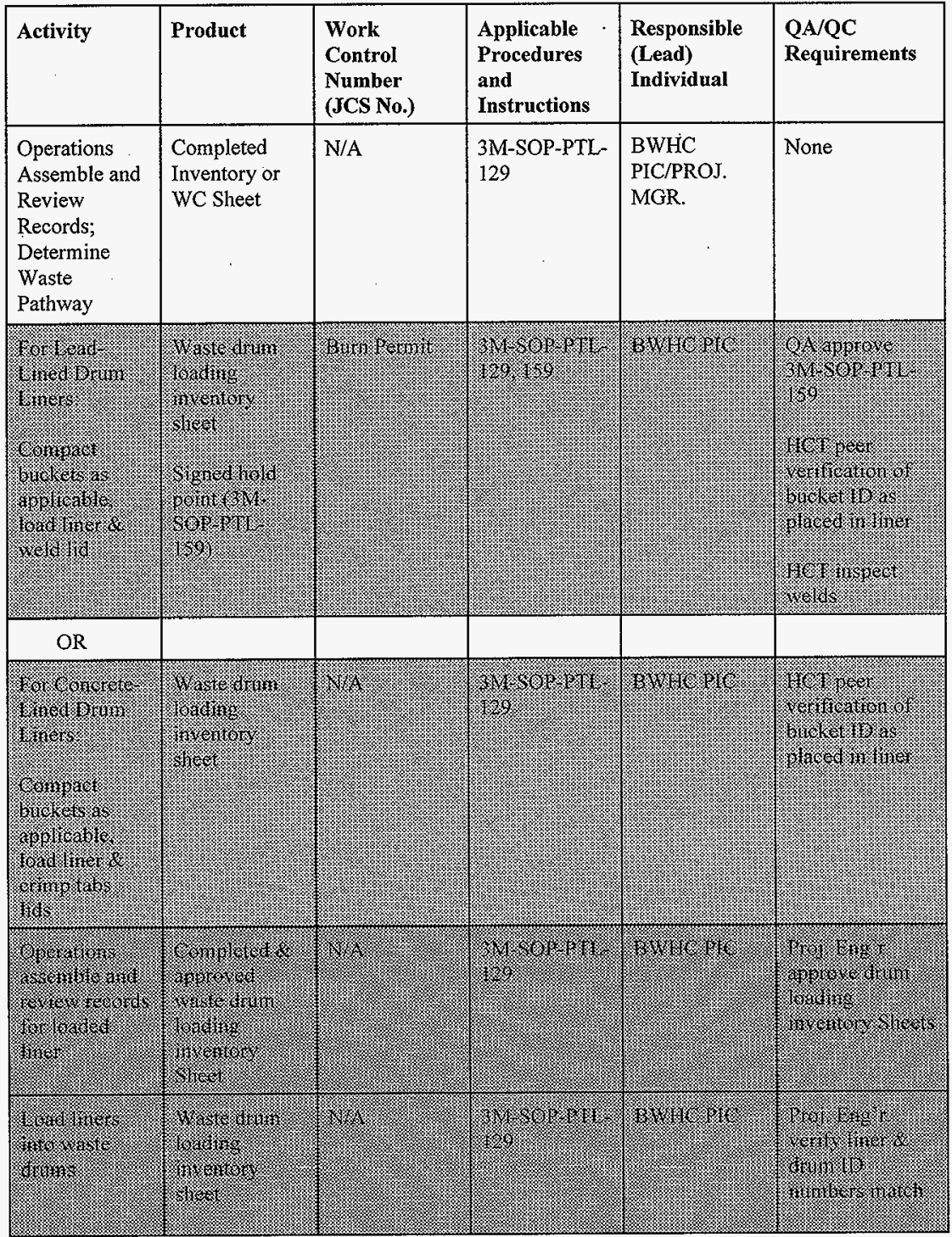


HNF-2223 Rev. 0

Table 1 (continued)

\section{K7FOA 327 LEGACY WASTE PROJECT QUALITY CONTROL MATRIX}

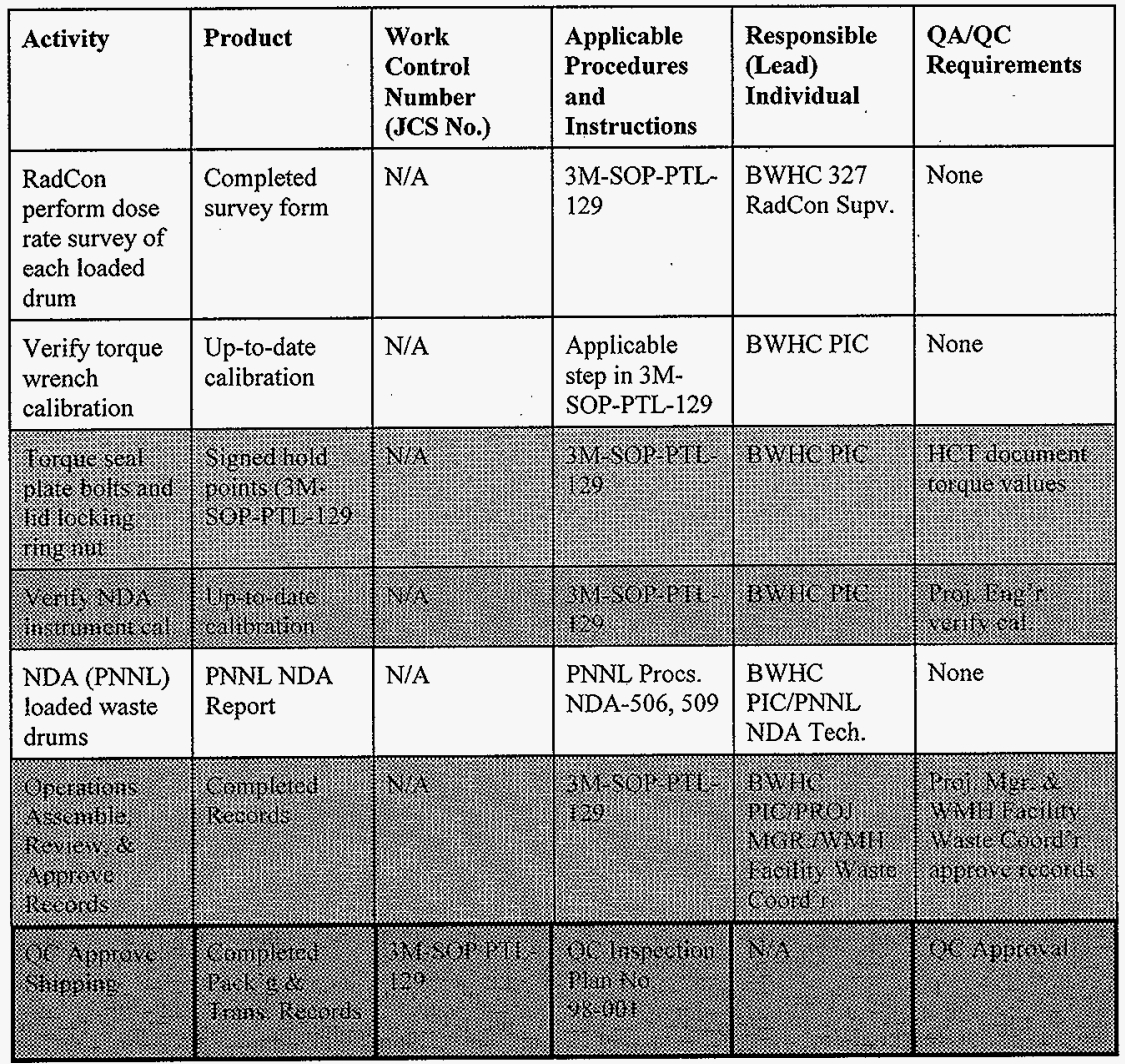

NOTES:

1. Shaded areas indicate in-house "check points" and bold borders indicate QA/QC hold points.

2. BWHC Operating Procedure titles are as follows:

3M-SOP-PTL-118 "Sample Material Transfers and Inventory Postings"

3M-SOP-PTL-129 "In-Cell Compacting and Packaging of TRU Waste for Disposal (A-Cell)"

3M-SOP-PTL-143 "Removal/Reinstallation of Solid Access Plugs and Slide Plugs"

3M-SOP-PTL-159 "A-Cell RHTRU Waste Package Welding Procedure"

3M-SOP-PTL-167 "Receiving, Loading/Unloading, and Shipping SERF Cask"

3M-SOP-PTL-168 "Receiving, Loading/Unloading, and Shipping Waste Cask"

3. QA Inspection Plan No. 98-001

4. PNNL Procedures for NDA services:

NDA-506 "Segmented Gamma Scan Neutron Assay System

NDA-509 "Radioactive Materials Holdup Measurements" 